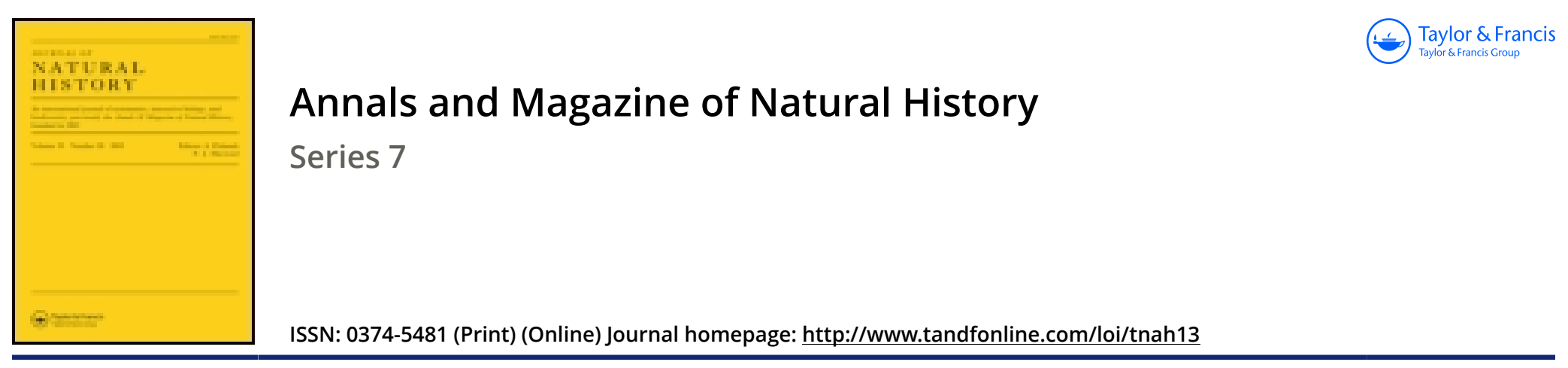

\title{
XX.-On the squirrels of the sciurus Prevostii group
}

\section{J.L. Bonhote B.A.}

To cite this article: J.L. Bonhote B.A. (1901) XX.-On the squirrels of the sciurus Prevostii group , Annals and Magazine of Natural History, 7:38, 167-177, DOI: 10.1080/00222930108678453

To link to this article: http://dx.doi.org/10.1080/00222930108678453

册 Published online: 29 Sep 2009.

Submit your article to this journal

Џ Article views: 5

Q View related articles $₫$ 
$c^{2}$. Tail black.

$c^{3}$. Annulations on hairs of back broad. Sc. e. erythogaster

$d^{3}$. Annulations on hairs of back narrow. Sc. e. punctatissimus.

$b^{1}$. Tail-hairs with fulvous tips.

$a^{2}$. Underparts uniformly coloured .... Sc. thaiwanensis Roberti.

$b^{2}$. Underparts with grizzled median

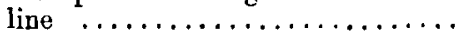

B. Underparts same colour as the back ....

Sc. t. centralis.

C. Underparts vinaceous (vinaceous rufous, Sc. t. typicus. Ridyway).

$a^{1}$. Underparts uniformly coloured.

$a^{2}$. Back brownish ................

$b^{2}$. Back greyish

Sc. castaneoventris typicus.

$b^{1}$. Underparts with grizzled median live.

$a^{2}$. Rufous area narrow...$\ldots \ldots \ldots$, sc. c. Gordoni.

$b^{2}$. Rufous area broad ............... Sc. c. griseopectus.

D. Underparts yellow $\ldots \ldots \ldots \ldots \ldots \ldots \ldots$. Sc. Styani.

E. Underparts black .................. Sc. melanogaster.

\section{XX.-On the Squirrels of the Sciurus Prevostii Group.} By J. L. Bonhote, B.A.

THIs group of squirrels, like the other groups with which I have already dealt, shows clearly that, although a certain amount of variation may be found in individuals from the same locality, yet when a large series comes to be examined there is no doubt as to the locality from which any particular individual may have come, and the differences, although in some instances slight, are in all cases constant. From the fact that the various races are geographical, it necessarily follows that there must be intermediate forms, and some of the races about to be described show this intergradation in a very marked degree.

For example Sciurus Caroli, described in this paper, is a very constant race and markedly distinct from Sciurus Caroli griseicauda, which, on the other hand, although constant in its essential characters, shows a wide range of individual variation.

Another point to be noted in regard to this paper is the case of Sciurus atricapillus from S.W. Borneo. 'There are no specimens in the Museum from that locality, so that one is unable to judge whether the differences between Sc. atricapillus and Sc. Caroli should entitle them to rank as species or subspecies. I have therefore described the latter as a new species, though the advent of further material may prove it to be only a subspecies of Sc. atricapillus. 
The same remarks hold good with regard to $S c$. baluensis from Borneo and Sc. erythromelas and Sc. Schlegeli from Celebes. I am inclined to believe that further investigation will prove them to be races of one and the same species, but from lack of sufficient material and data I have thought it best, considering the distinctness as a rule of Bornean and Celebean species, to keep them separate.

The next point of note is the question of the exact locality of Sc. redimitus. The original describer states that it was collected in the East Indies; Temminck imagines it to have come from S. Borneo; while Schlegel, correcting the lastnamed author, states that it came from Sumatra and that he removed it from the original spirit in which it was preserved. It is impossible to say which, if any, of these statements is correct ; from the original description it seems to agree most nearly with the race from Selangore, but in the face of Schlegel's statement that it came from Sumatra it seems best to leave the matter open for the present.

Owing to lack of material, I have omitted descriptions of the skulls, although from those examined there seems to be very little, if any, variation among them.

We have thus seven species in this group:-

(1) Sciurus Prevostii, from the Malay Peninsula, Sumatra, and Borneo.

(2) Sciurus atricapillus, from S.W. Borneo.

(3) Sciurus Caroli, from Sarawak and the Baram district, Borneo.

(4) Sciurus baluensis, from N.W. Borneo and the Baram district.

(5) \& (6) Sciurus erythromelas and Sc. Schlegeli, from Celebes.

(7) Sciurus rufoniger, from Borneo.

Of Sciurus Prevostii ten (or probably only eight) races may be distinguished :-

(1) Sciurus Prevostii typicus, from Malacca and the Malay Peninsula.

(2) Sciurus Prevostii Humei, from Selangore.

(3) Sciurus Prevostii sarawakensis, from Sarawak.

(4) Sciurus Prevostii kuchingensis, from Kuching, S.W. Sarawak.

(5) Sciurus Prevostii navigator, from Sirhassen Island.

(6) Sciurus Prevostii bangkanus, from the Island of Bangka. 
(7) Sciurus Prevostii borneoensis, from Pontianak, S.W. Borneo.

(8) Sciurus Prevostii redimitus, locality unknown.

(9) Sciurus Prevostii Raflesii, from Sumatra.

(10) Sciurus Prevostii rufogaster, from China (doubtful).

With regard to the last two forms, there is not sufficient material to judge whether they be distinct or not. The types, which are the only specimens I have had an opportunity of examining, seem to me identical, and it is quite probable that they both came from the same place, as the exact locality of rufogaster is very doubtful.

In addition to the forms mentioned above, Mr. G. Miller, Jr., has recently described * two other insular forms, viz. :-

Sciurus mimellus, from Pulo Wai, Tambelan Island. Sciurus mimiculus, from Ste. Barbe Island.

They are distinguished from Sc. Prevostii typicus by the narrowness of the white band, especially on the thighs, and, as might be expected, are most nearly allied to Sc. $P$. navigator of this paper.

Sc. mimiculus differs from Sc. mimellus only in its smaller size.

Sciurus Prevostii typicus, Desm.

Sciurus Prevostii, Desm. Mamm. 1822, p. 335; Schlegel, Nederland. Tijdschr. vol. i. 1863, p. 24, pl. i. fig. 1; Anderson, Zool. Res. Yunnan t, 1878, p. 269 ; Flower, P. Z. S. 1900, p. 358.

General colour above deep black, bordered on either side from the tip of the nose to the outer side of the limbs by a broad white stripe, which has a tendency to be slightly grizzled on the cheeks. The whole of the underparts, including the outer side of the fore limbs, deep chestnut. There is a short black stripe, always present, but of varying width and intensity, running between the thighs and the shoulders immediately beneath the white lateral stripe. Tail uniformly black throughout, frequently bleaching to a light brown.

Dimensions (from skin):-Head and body 250 millim., tail 270 , hind foot (s. u.) 58 .

Hab. Malay Peninsula ; Singapore, Malacca, Penang.

* Proc. Wash. Ac. Sc. vol. ii. p. 218 (1900).

+ A full synonymy for the whole group will be found in Dr. Anderson's work quoted above. 
Sciurus Prevostii Humei, subsp. n.

Sciurus Prevostii, Desm., Thos. P. Z. S. 1886, p. 76.

Differs from the preceding form in the red of the underparts covering the whole of the fore limbs and spreading upwards over the shoulders till it meets the black of the back. The cheeks are grizzled, but behind and below the ear is a pure white patch. The hind feet are of a more brilliant and purer chestnut than in $S$. $P$. typicus, and the black sublateral stripe is not always present.

Dimensions similar to the last.

$H a b$. Klang, Selangor.

Type, B.M. 85. 8. 1. 230. Collected 4th April, 1879, by Mr. W. Davison.

\section{Sciurus Prevostii sarawakensis, Gray.}

Macroxus sarawakensis, Gray, Ann. \& Mag. Nat. Hist. xx. 1867, p. 277.

This race, of which only two specimens are known, is very distinct from the preceding forms. One of the chief features (common to this and the next) is the tail, the hairs of which have long light fulvous tips, which, though sometimes worn, are always to be seen. The black of the back is somewhat restricted; it narrows down to a stripe over the shoulders, and, broadening out over the back, narrows again over the thighs to a stripe about the width of the tail. The lateral stripe, which is narrow and of a dirty white between the limbs, broadens out to cover the whole of the thighs, where it is of a light fulvous, each hair being black at its base. The whole of the underparts, shoulders, sides of neck, face, and limbs are of a deep chestnut, slightly tinged with fulvous over the shoulders, and with a tendency to being grizzled on the cheeks. 'There is no sign of the sublateral black stripe.

Dimensions as in Sc. Prevostii typicus.

Hab. Sarawak.

Type $q$, B.M. 59. 9. 19. 5. Collected by Mr. A. R. Wallace.

A second specimen was collected by Mr. Charles Hose on the River Batang Lupar, fifty miles from the coast, in S.W. Sarawak, August 1892.

Sciurus Prevostii kuchingensis, subsp. n.

Very similar to Sciurus Prevostii sarawakensis, but differs in the lateral stripe being pure white, in having a much larger extent of black on the neck and back, and in the fulvous tips to the hairs of the thighs being small, so that the 
thighs have a greyish grizzled appearance; the shoulders, sides of the neck, and cheeks are also grizzled, although in some cases they are suffused with rufous. Tail with broad fulvous tips to all the hairs except those forming the end.

Dimensions as in Sc. Prevostii typicus.

Hab. Kuching, Sarawak.

Type 9, B.M.99. 12. 9. 47. Collected 15th Sept., 1896, by Mr. Charles Hose.

\section{Sciurus Prevostii navigator, subsp. n.}

Specimens from the island of Sirhassen form a very distinct race. They are much smaller in size, the chestnut of the underparts is far brighter and more orange in tint. The lateral line, which starts from the shoulders, is narrow, clear, and well marked, and spreads out over the thighs as in Sc. P. sarawakensis. The shoulders are of a light fulvous, which becomes darker and grizzled on the cheeks and sides of the head. The tail is pure black, and its hairs show no signs of fulvous tips.

Dimensions (from skin) :-Head and body 235 millim., tail 225 , hind foot 47 .

Hab. Sirhassen Island.

Type, B.M. 94. 9. 28. 14. Collected Sept. 22, 1893, by Mr. A. Everett.

\section{Sciurus Prevostii bangkanus, Schlegel.}

Sciurus Prevostii bangkanus, Schlegel, op. cit. p. 26, pl. i. fig. 2.

Most nearly resembles Sc. P. Humei from Klang, but may be distinguished by the cheeks and sides of the neck being iron-grey instead of white.

Dimensions as in Sc. P. typicus.

$H a b$. Island of Bangka.

\section{Sciurus Prevostii borneoensis * (Müller \& Schlegel).}

Sciurus Prevestii, var borneoensis, Müll. et Sch., Verhand. over de Nat. Gesch. Overz, Bezitt., Zool. p. 86 (1839-44).

Sciurus Prevostii borneoensis, Schlegel, op, cit. p. 26, pl. i. fig. 3.

This form, as one might expect, is most closely allied to Sc. $P$. kuchingensis from Kuching, which is, in fact, not very far north of Pontianak. It is distinguished by the fact that the black of the back is not sharply defined from the lateral

* This name antedates that given by Gray to a Bornean form of S. hippurus (Ann. \& Mag. Nat. Hist. xx. 1867, p. 283). For that I would suggest the name of $S$. hippurus Grayi. 
stripe as in all the other races, but the hairs of the back as they approach the stripe are more or less broadly tipped with fulvous, so that the sides become grizzled like the thighs.

Dimensions as in Sc. P. typicus.

Hab. Pontianak, S.W. Borneo.

\section{Sciurus Prevostii Rafflesi, Vigors \& Horsf.}

Sciurus Raffesi, Vigors \& Horsf. Zool. Journ. no. xii. 1828, vol. iv. pl. iv. p. 113; Temm. Esq. Zool. Guin. p. 242 (1853).

Sciurus rufogularis, Gray, Ann. \& Mag. Nat. Hist. vol. x. 1842, p. 263. Sciurus Prevostii sumatranus, Schlegel, op. cit. p. 25.

A very distinct and easily recognizable form. The whole of the upper parts and tail are of a deep black. The white lateral stripe, which is broad and well defined, starts behind the shoulders and spreads out over the outer side of the hind limbs. The underparts, including the shoulders, fore limbs, inner side of hind limbs, and feet, are of a very deep chestnut. The cheeks and sides of the neck are grizzlod irongrey; a patch on the side of the nose pure white.

Dimensions as in Sc. P. typicus.

Hab. Sumatia.

Co-type, B.M. 84. 6. 3. 8. Collected by Sir 'T. S. Raffles, formerly in the Zoological Society's Museum. Received from the late Dr. Crisp's collection.

I have united under this species Sc. rufogularis of Gray, which was stated to have come from China, although it most probably did not. It differs from Sc. P. Rafflesi only in size, and the other differences mentioned by Gray do not seem to hold good.

\section{Sciurus Prevostii redimitus, Boon Mesch.}

Sciurus redimitus, Boon Mesch, Nieu. Verhandl. Nederl. Inst. Amsterd. 1829 , vol. ii. p. 243 , pl.

This form seems to be very nearly allied to Sc. Prevostii Humei, differing chiefly in being lighter in colour, and this might possibly be due either to bleaching or to the spirit in which it was preserved. There seems, however, to be great doubt as to its locality; and in view of the fact that Schlegel states positively that it came from Sumatra, it seems best to leave it as a separate race for the present till further information is forthcoming. 
The next species with which we have to deal is

\section{Sciurus atricapillus, Schlegel.}

Sciurus atricapillus, Schlegel, op. cit. p. 27, pl. ii. fig. 1.

Sciurus redimitus, Boon Mesch, Temm. Esq. Zool. Guin. p. 245 (partim) (1853).

In this species, according to the describer, the underparts and inner sides of limbs alone are chestnut. The tail is black, shading to rufous-brown. The white lateral stripe is narrower and the sublateral black stripe much broader than in Sc. Prevostii typicus. The top of the muzzle and feet are black, the remainder, including all the upper parts, is covered with black hairs annulated with fulvous, which is rather paler on the thighs, cheeks, and sides of the neck.

Hab. Kapouas River, east of Pontianak, Borneo.

The next is a species in which we get a highland and a lowland form, the limit being roughly at 1000 feet, and neither of these appears to have been hitherto described. They come from the Baram district of Sarawak, and the large series in the Museum has been almost entirely collected by Mr. Charles Hose. For the lowland form I propose the name

\section{Sciurus Caroli, sp. n.}

Sciurus Prevostii, Desm., Hose, Mamm. Borneo, 1893, p. 45 (partim).

Top of the head, neck, and shoulders dirty fulvous white, each hair being dark at its base, with a broad fulvous tip. Remainder of back narrowing dowu towards the root of the tail dingy black, each hair being black, with two narrow fulvous annulations. Lateral stripe from behind the shoulders and the whole of the outer side of the thighs and hind limbs white. Underparts, feet, sides of neck, cheeks, face, and rim round eye pure chestnut, also the ears, although these latter show a tendency to become grizzled. Tail broadly annulated with black and pale fulvous. Sublateral black stripe very faint or absent.

Dimensions (from skin):-Head and body 275 millim., tail 250 , hind foot 55 .

Hub. Marudi River, Baram district.

Type \&, B.M. 99. 12. 9. 59. 26th May, 1898. Collected by and named in honour of Mr. Charles Hose.

Ann. \& Mag. N. Hist. Ser. 7. Vol. vii. 
In some specimens there is a tendency for the shoulders to become tinged with rufous. I have examined specimens of this squirrel from the Miri River and from the lower slopes of Mount Dulit.

Sciurus Caroli griseicauda, subsp. n.

Sciurus Prevostii, Desm., Hose, loc. cit. p. 45 (partim).

The whole of the upper parts, including the feet, crown of head, sides of face and neck, and tail, of a uniform grizzled greyish, darker on the fore limbs and slightly lighter on the sides of the neck and thighs, occasionally white on the latter, the sides of the face more or less suffused with rufous. The lateral white line narrow and starting well behind the shoulder, but widening out slightly on reaching the thighs. The sublateral black stripe always broad and well marked. Underparts, inner sides of limbs, and a ring round the eye chestnut, as in the preceding form; the insides of the ears are also slightly suffused with the same colour.

Dimensions as in Sciurus Caroli.

$H a b$. Mount Kalulong, Baram district, alt. 2000 feet.

Type ơ, B.M. 93. 6. 1. 5. February. Presented by Mr. Charles Hose.

This squirrel, which shows a wide limit of variation, with a great tendency towards the preceding form, may nevertheless always be readily distinguished by the very broad and well-marked black sublateral stripe, which in $S c$. Caroli typicus is generally absent, but if present is very faintly developed. It appears widely distributed in the Baram district, specimens having been received from most of the mountains, including Mount Dulit, Batu Song, Niah, Bakong.

\section{Sciurus baluensis, sp. n.}

Whole of the upper parts, including the sides, neck and face, and outer sides of the limbs and feet, uniform grizzled brownish olive, slightly darker along the median line, the top of the nose, feet, and sides of the face being more or less suffused with chestnut, each hair being dark brown with one or two fulvous annulations. The lateral light stripe is short, narrow, and light yellow in colour, and loses itself before reaching the thighs. The sublateral black stripe is broad and well marked and of equal length with the lighter stripe. The remainder of the underparts, muzzle, and a ring round the eye chestnut. Tail deep black, with no sign of annulations. 
Dimensions (from skin):-Head and body 275 millim., tail 280 , hind foot 55 .

Hab. Mount Kina Balu, Borneo, alt. 1000 feet.

Type đa, B.M. 95. 10.4.11. Collected March 1887 by Mr. J. Whitehead. Presented by Mr. Oldfield Thomas.

There are also specimens from Mount Dulit up to 5000 feet in no way differing from the above.

I am somewhat doubtful as to the specific distinctness of this form from Sc. erythromelas of Schlegel from Celebes; but in view of the distinctness of the Bornean fauna from that of Celebes, it seemed best to consider it specifically distinct until an opportunity occurs of comparing it with Celebean specimens.

Sciurus baluensis suffusus, subsp. $\mathrm{n}$.

Considerably smaller than the previous form. The whole of the upper parts as in Sc. baluensis, but the colour absolutely uniform throughout and without any rufous on the feet or top of the nose. The sides of the face and a ring round the eye are pure chestnut, but the muzzle is paler. The tail is similar in colour to the back. The presence of the light lateral stripe is only faintly indicated by a lighter tinge about the centre of each side, and the sublateral black stripe, although distinct, is very short.

Dimensions (from skin):- Head and body 200 millim., tail 185, hind foot 43 .

Hab. Tutong River, N.W. Borneo.

Type, B.M. 98.9.28. 7. Collected by Dr. Waterstradt.

\section{Sciurus erythromelas, Temm.}

Sciurus erythromelas, Temm. Esq. Zool. Guin. p. 248 (partim) (1853); Schlegel, op. cit. p. 28.

Upper parts lustrous black, slightly suffused with rufous on the cheeks, sides of the neck, shoulders, and outer side of the thighs. The underparts, including the feot and inner sides of the limbs, deep chestnut, the feet, however, possessing black hairs as well. The tail has a reddish-brown hue, and the light annulations to the hairs of the sides form themselves into a faint lateral stripe. Muzzle whitish.

Dimensions as in Sc. atricapillus.

Hab. Menado, N.W. Celebes.

This description and that which follows have been takeu from Schlegel, as I have had no specimens for examination. 


\section{Sciurus Schlegeli, Gray.}

Sciurus erythrogenys, Schlegel, op. cit. p. 29 (nec Waterhouse).

Sciurus Schlegeli, Gray, Ann. \& Mag. Nat. Hist. xx. 1867, p. 278.

The hairs of the upper parts black, with fulvous annulations in such a manner that the general colour is black on the head, neck, back, and feet, the light annulations being most marked on the sides, where they form a faint stripe, which is bordered by a distinct sublateral black stripe. The underparts and the sides of the face chestnut.

Dimensions :- Head and body 200 millim., tail 225.

Hab. Kenia, N. Celebes.

\section{Sciurus rufoniger, Gray.}

Sciurus rufonigra, Gray, Ann. \& Mag. Nat. Hist. x. 1812, p. 263; List Mamm. B. II. 1843, p. 142 (nec Puch.).

Sciurus rufoniger, Gray, Ann. \& Mag. Nat. Hist. xx. 1867, p. 278.

This species, which is known only from the type, has the whole of the head, back, tail, and outer sides of limbs and feet rich black, with a very faint but distinct pale tinge, forming a light lateral stripe, which spreads out over the thighs. Underparts and inner sides of limbs rich chestuut.

Dimensions apparently as in the larger forms of this group. Hab. Unknown.

Type, B.M. 38. 3. 13. 29.

Sciurus rufoniger pluto, Gray.

Macroxus pluto, Gray, Ann. \& Mag. Nat. Hist. xx. 1867, p. 283.

Whole of head, upper parts, outer sides of limbs, feet, and tail rich glossy black. 'The remainder dark chestnut. In some individuals there is a faint but clear short white lateral stripe.

Dimensions :- Head and body 200 millim., tail 220, hind foot 50 .

Hab. Sarawak, Borneo.

Type, B.M. 56. 9. 19.6.

This form seems to be generally distributed in Borneo and some of the neighbouring islands; there are also specimens from Sumatra.

Key to the Group.

A. Hairs on the back not annulated.

$a^{1}$. Whitish lateral stripe present. Face and cheeks not black, 


\section{of the Sciurus Prevostii Group.}

$a^{2}$. White stripe unbroken from tip of nose to heel of hind foot ........

$b^{2}$. White stripe broken.

$a^{3}$. Hairs of tail with no fulvous tips.

$a^{4}$. Light part of thigh not grizzled.

$a^{5}$. Shoulders fulvous.

$a^{b}$. Sides of face and neck iron-

grey.................

$b^{6}$. Sides of face and neck white.

Sc. P. bangkanus.

Sc. P. Humer.

Sc. P. redimitus.

$b^{5}$. Shoulders chestnut.

$c^{6}$. Sides of face and ears iron-

grey...............

$b^{4}$. Light part of thigh slightly

Sc. Prevostii typicus. grizzled.

$c^{5}$. Face and shoulders fulvous.

Smaller ................

$b^{3}$. Hairs of tail with fulvous tips.

Sc. P. Rafflesii.

$b^{4}$. Light part of thigh grizzled.

$a^{5}$. Sides of body $u b o v e$ the white lateral stripa grizzled ....

$b^{5}$. Sides of body abuve the white lateral stripe not grizzled . .

$b^{1}$. Whitish laterul stripe, if present, very faint. Face and cheeks black.

$a^{2}$. Lateral stripe very faint, but spreading over thighs .............

$b^{2}$. Lateral stripe absent, or sometimes very faint and short, never on

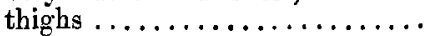

B. Hairs on the back annulated.

$a^{1}$. Lateral light stripe present.

$a^{2}$. Upper part of thighs lighter than back.

$a^{3}$. Feet rich chestnut . .........

$b^{3}$. Feet grizzled greyish.

$a^{4}$. Eye surrounded with rufous ring $\ldots \ldots \ldots \ldots \ldots \ldots$

$b^{4}$. Eye not surrounded with rufous

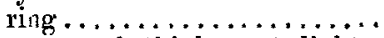

$b^{2}$. Upper part of thighs not lighter than back.

$a^{3}$. Larger, length $275 \mathrm{~mm}$. Lateral light stripe pale yellow........

$b^{3}$. Smaller, lenyth $200 \mathrm{~mm}$. Lateral light stripe nearly absent. $a^{4}$. Feet grizzled ............

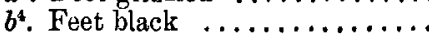

b'. Lateral light stripe absent.........

Sc. P. navigator.

Sc. P. sarawakensis.

Sc. P. borneoensis.

Sc. P. kuchingensis.

Sc. rufoniger typicus.

Sc. rufoniger pluto.

Sc. Caroli typicus.

Sc. C. griseicauda.

Sc. atricapillus.

Sc. baluensis typicus.

Sc. b. suffusus.

Sc. Schlegeli.

Sc. erythromelas. 